\title{
The alternative approach to the preparation of complex calcium phosphates and their characterization
}

\author{
Ok.Livitska, N.Strutynska, Ol.Livitska, N.Slobodyanik \\ Chemistry Department, T. Shevchenko National University of Kyiv, 64/13 \\ Volodymyrska Str., 01601 Kyiv, Ukraine
}

Received February 8, 2017

\begin{abstract}
In this paper a new approach to the preparation of complex calcium-containing phosphates using molten chlorides and nitrates of alkaline metals as fluxes was described. The main advantages of used technique for synthesis of double phosphates comparing with traditional methods (solid state reactions or crystallization of a high temperature self-flux) were discussed. It was found that the phase composition of obtained crystalline products depends on type of salt melts, nature of alkaline metals and type of initial components. Formation conditions for compounds $\mathrm{M}^{\prime} \mathrm{CaPO}_{4}, \mathrm{M}_{2} \mathrm{CaP}_{2} \mathrm{O}_{7}\left(\mathrm{M}^{\mathrm{l}}-\mathrm{Na}, \mathrm{K}\right), \mathrm{Ca}_{2} \mathrm{P}_{2} \mathrm{O}_{7}, \mathrm{Ca}_{2} \mathrm{PO}_{4} \mathrm{Cl}$ and $\mathrm{Ca}_{10}\left(\mathrm{PO}_{4}\right)_{6} \mathrm{Cl}_{2}$ were established. The synthesized phosphates were characterized using powder $\mathrm{X}$-ray diffraction, Fourier transform infrared spectroscopy and optical microscopy.
\end{abstract}

Keywords: calcium phosphates, molten chlorides and nitrates, flux.

Показан новый подход к получению сложных кальций фосфатов с использованием расплавов хлоридов и нитратов щелочных металлов. Рассмотрены основные преимущества применяемого метода для получения двойных фосфатов, по сравнению с традиционными (твердофазным или кристаллизацией высокотемпературных растворов-расплавов). Показано, что фазовый состав полученных кристаллических продуктов зависит от типа солевого расплава, природы щелочного металла и типа исходных компонентов. Установлены условия формирования соединений состава: $\mathrm{M}^{\prime} \mathrm{CaPO}_{4}, \mathrm{M}_{2}^{\prime} \mathrm{CaP}_{2} \mathrm{O}_{7}\left(\mathrm{M}^{\prime}-\right.$ $\mathrm{Na}, \mathrm{K}), \mathrm{Ca}_{2} \mathrm{P}_{2} \mathrm{O}_{7}, \mathrm{Ca}_{2} \mathrm{PO}_{4} \mathrm{Cl}$ и $\mathrm{Ca}_{10}\left(\mathrm{PO}_{4}\right)_{6} \mathrm{Cl}_{2}$. Синтезированные фосфаты исследованы с использованием методов порошковой рентгенографии, ИК спектроскопии и оптической микроскопии.

Альтернативний підхід щодо синтезу складних кальцій фосфатів та їх дослідження.Ок.В.Лівіцька, Н.Ю.Струтинська, Ол.В.Лівіцька, М.С.Слободяник.

Розглянуто новий підхід щодо одержання складних кальційвмісних фосфатів 3 використанням розплавів хлоридів і нітратів лужних металів, як середовища синтезу. Розглянуто основні переваги застосованого методу для одержання подвійних фосфатів, у порівнянні з традиційними (твердофазним чи кристалізацію високотемпературних розчинрозплавів). Показано, що фазовий склад одержаних кристалічних продуктів залежить від типу сольового розплаву, природи лужного металу та типу вихідних компонентів. Встановлено умови формування сполук складів: $\mathrm{M}^{\mathrm{l}} \mathrm{CaPO}_{4}, \mathrm{M}_{2} \mathrm{CaP}_{2} \mathrm{O}_{7}\left(\mathrm{M}^{\mathrm{l}}-\mathrm{Na}, \mathrm{K}\right), \mathrm{Ca}_{2} \mathrm{P}_{2} \mathrm{O}_{7}$, $\mathrm{Ca}_{2} \mathrm{PO}_{4} \mathrm{Cl}$ та $\mathrm{Ca}_{10}\left(\mathrm{PO}_{4}\right)_{6} \mathrm{Cl}_{2}$. Синтезовані фосфати охарактеризовано 3 використанням методів порошкової рентгенографії, ІЧ спектроскопії та оптичної мікроскопії.

\section{Introduction}

The complex calcium phosphates and their substituted analogs have been extensively investigated in recent years due to perspectives of practical applications in various fields of technology. Such compounds are characterized by a great variety of compositions, structure types and useful 
properties. In particular, the sodium- or potassium-containing orthophosphates $\mathrm{M}^{\mathrm{l}}$ $\mathrm{CaPO}_{4}\left(\mathrm{M}^{\prime}-\mathrm{Na}, \mathrm{K}\right)$ doped lanthanides $\left(\mathrm{Eu}^{2+}, \mathrm{Ce}^{3+}, \mathrm{Dy}^{3+}, \mathrm{Tb}^{3+}\right)$ or transition metals ions $\left(\mathrm{Mn}^{2+}\right)$ are perspective luminescent materials and can be used in many areas, e.g., lighting, display, high-energy ray detection, multidimensional optical memory and imaging storage [1-14]. Such phosphors have a high thermal and chemical stability. Besides, $\beta-\mathrm{NaCaPO}_{4}$ is proposed to use as a component of biphasic biomaterial for skeletal repair [15].

Pyrophosphate $\mathrm{Ca}_{2} \mathrm{P}_{2} \mathrm{O}_{7}$ is a compound with dichromate structure. Its current applications lie mainly in the fields of luminescence, biomaterials and catalysis [1619].The crystal structure studies of $\mathrm{Ca}_{2} \mathrm{P}_{2} \mathrm{O}_{7}$ show that it exists in three different forms depending on the temperature of firing. $\beta-\mathrm{Ca}_{2} \mathrm{P}_{2} \mathrm{O}_{7}$ is tetragonal and the high temperature form of $\alpha-\mathrm{Ca}_{2} \mathrm{P}_{2} \mathrm{O}_{7}$ crystallizes in the monoclinic crystal system. $\alpha-\mathrm{Ca}_{2} \mathrm{P}_{2} \mathrm{O}_{7}$ builds up from $\mathrm{PO}_{4}$ - and $\mathrm{CaO}_{8}$-polyhedra while $\beta-\mathrm{Ca}_{2} \mathrm{P}_{2} \mathrm{O}_{7}$ has four non-equivalent ions $\mathrm{Ca}^{2+}$ in the crystal structure: two exhibit a coordination number of 7 , one of 8 and one of 9 [20]. $\beta-\mathrm{Ca}_{2} \mathrm{P}_{2} \mathrm{O}_{7}$ has excellent microwave dielectric properties that's why it can be used in the modern microwave communication system [21].

Compounds of the general composition of $\mathrm{M}_{2}{ }_{2} \mathrm{CaP}_{2} \mathrm{O}_{7}\left(\mathrm{M}^{\prime}-\mathrm{Na}, \mathrm{K}\right)$ may be viewed as the derivatives of $\alpha-\mathrm{Ca}_{2} \mathrm{P}_{2} \mathrm{O}_{7}$ structure with both $\mathrm{M}^{\prime}$ and $\mathrm{Ca}$ atoms which simultaneously accommodate one site, and the other site is occupied only by $\mathrm{M}^{\mathrm{l}}$ atom.

The phosphates $\mathrm{Na}_{2} \mathrm{CaP}_{2} \mathrm{O}_{7}$ and $\mathrm{K}_{2} \mathrm{CaP}_{2} \mathrm{O}_{7}$ belonging to triclinic (space group of $P-1$ ) [22] and monoclinic (space group $P 21 / n$ ) [23] crystal systems attract a great interest as catalysts of organic reactions [24-26] or hosts for luminescent materials [27, 28].

A very interesting field of research is associated with chloro-containing calcium phosphates $\mathrm{Ca}_{2} \mathrm{PO}_{4} \mathrm{Cl}$ and $\mathrm{Ca}_{10}\left(\mathrm{PO}_{4}\right)_{6} \mathrm{Cl}_{2}$. First compound crystallizes in the orthorhombic system (space group $P b c m$ ) and it is a high efficiency phosphor material [2932]. Second substance belongs to the hexagonal crystal system. It exhibits antibacterial properties when doped with silver ions. Chlorapatite matrix also can be used for removal of heavy metals. Besides that, the multifunctional powders on the base of $\mathrm{Ca}_{10}\left(\mathrm{PO}_{4}\right)_{6} \mathrm{Cl}_{2}$ are promising biomarkers in bone replacement materials [33-35].
The main disadvantages of traditional methods of calcium phosphates preparation (solid state reactions and crystallization of a high temperature self-flux) are the high temperature and the duration of synthesis, and the formation of impurity phases. Our early reported results showed that using of molten nitrates and chlorides as media for interaction between solids is very convenient method for synthesis of some complex phosphates.Such approach allows decreasing synthesis time and temperature comparing with traditional methods [36-38].

This paper is dedicated to investigation of preparation of Ca-containing complex phosphates in the molten chlorides and nitrates. Another goal was to get the some relationships between the nature of initial components, reactions conditions and phase composition of obtained products.

The synthesized compounds have been characterized using the powder X-ray diffraction, Fourier transform infrared spectroscopy, elemental analysis, and jptical microscopy.

\section{Experimental}

\subsection{Samples preparation}

The complex phosphates were prepared using two ways: the interaction of mixtures $\mathrm{CaCO}_{3}$ and $\mathrm{M}^{\prime} \mathrm{H}_{2} \mathrm{PO}_{4}\left(\mathrm{M}^{\prime}-\mathrm{Na}, \mathrm{K}\right)$ in salt melts or interaction of $\mathrm{CaHPO}_{4}$ (or $\mathrm{Ca}\left(\mathrm{PO}_{3}\right)_{2}$ ) with molten chloride or nitrate $\left(\mathrm{M}^{\prime} \mathrm{Cl}, \mathrm{M}^{\prime} \mathrm{NO}_{3}\right.$, $\mathrm{CaCl}_{2}$ or $\left.\mathrm{Ca}\left(\mathrm{NO}_{3}\right)_{2}\right)$. The molar ratio $\mathrm{M}^{\mathrm{l}} \mathrm{H}_{2} \mathrm{PO}_{4} / \mathrm{CaCO}_{3}$ was 1 or 2 . Salts media were taken in a 5-7 weight excess according to the initial mixture of precursors. The interaction temperature was chosen taking into account the melting point of corresponding nitrates or chlorides (Table).

All initial components were of an analytical grade. The starting compounds in appropriate amounts were ground in an agate mortar and heated in porcelain crucibles to $450^{\circ} \mathrm{C}\left(\mathrm{M}^{\prime} \mathrm{NO}_{3}\right), 600^{\circ} \mathrm{C}\left(\mathrm{Ca}\left(\mathrm{NO}_{3}\right)_{2}\right)$ or $810^{\circ} \mathrm{C}$ $\left(\mathrm{M}^{\prime} \mathrm{Cl}, \mathrm{CaCl}_{2}\right)$ with a rate of $4-5^{\circ} \mathrm{C} / \mathrm{min}$. The heterogeneous systems were kept under isothermal conditions during $6-7$ or $3-5 \mathrm{~h}$ for nitrate or chloride systems, respectively. After that the temperature was decreased to $25^{\circ} \mathrm{C}$ and the crystalline phases were separated from soluble salts by washing with warm distilled water and then dried in air at $100^{\circ} \mathrm{C}$.

\subsection{Samples characterization}

The phase composition of the obtained samples was determined using powder X-ray diffraction (XRD). The diffractometer Shi- 
Ok.Livitska et al. / The alternative approach to the ...

Table. The results of phase analysis for crystalline products obtained at different conditions

\begin{tabular}{|c|c|c|c|}
\hline Flux $T,{ }^{\circ} \mathrm{C}$ & Precursors & $\mathrm{P} / \mathrm{Ca}$ & $\begin{array}{l}\text { Phase composition of } \\
\text { products }\end{array}$ \\
\hline \multirow[t]{4}{*}{$\mathrm{NaCl} 810^{\circ} \mathrm{C}$} & \multirow[t]{2}{*}{$\mathrm{CaCO}_{3}+\mathrm{NaH}_{2} \mathrm{PO}_{4}$} & 1 & \multirow[t]{4}{*}{$\mathrm{Ca}_{10}\left(\mathrm{PO}_{4}\right)_{6} \mathrm{Cl}_{2}$} \\
\hline & & 2 & \\
\hline & $\mathrm{CaHPO}_{4}$ & 1 & \\
\hline & $\mathrm{Ca}\left(\mathrm{PO}_{3}\right)_{2}$ & 2 & \\
\hline \multirow[t]{4}{*}{$\mathrm{KCl} 810^{\circ} \mathrm{C}$} & \multirow{2}{*}{$\mathrm{CaCO}_{3}+\mathrm{KH}_{2} \mathrm{PO}_{4}$} & 1 & $\mathrm{KCaPO}_{4}$ \\
\hline & & 2 & $\mathrm{~K}_{2} \mathrm{CaP}_{2} \mathrm{O}_{7}$ \\
\hline & $\mathrm{CaHPO}_{4}$ & 1 & $\mathrm{KCaPO}_{4}$ \\
\hline & $\mathrm{Ca}\left(\mathrm{PO}_{3}\right)_{2}$ & 2 & $\mathrm{~K}_{2} \mathrm{CaP}_{2} \mathrm{O}_{7}$ \\
\hline \multirow{2}{*}{$\begin{array}{l}\mathrm{CaCl}_{2} \\
810^{\circ} \mathrm{C}\end{array}$} & $\mathrm{CaHPO}_{4}$ & 1 & \multirow[t]{2}{*}{$\mathrm{Ca}_{2} \mathrm{PO}_{4} \mathrm{Cl}$} \\
\hline & $\mathrm{Ca}\left(\mathrm{PO}_{3}\right)_{2}$ & 2 & \\
\hline \multirow{2}{*}{$\begin{array}{r}\mathrm{NaNO}_{3} \\
450^{\circ} \mathrm{C}\end{array}$} & $\mathrm{CaHPO}_{4}$ & 1 & $\mathrm{NaCaPO}_{4}$ \\
\hline & $\mathrm{Ca}\left(\mathrm{PO}_{3}\right)_{2}$ & 2 & $\mathrm{Na}_{2} \mathrm{CaP}_{2} \mathrm{O}_{7}$ \\
\hline \multirow{2}{*}{$\begin{array}{l}\mathrm{KNO}_{3} \\
450^{\circ} \mathrm{C}\end{array}$} & $\mathrm{CaHPO}_{4}$ & 1 & $\mathrm{Ca}_{2} \mathrm{P}_{2} \mathrm{O}_{7}$ \\
\hline & $\mathrm{Ca}\left(\mathrm{PO}_{3}\right)_{2}$ & 2 & $\mathrm{~K}_{2} \mathrm{CaP}_{2} \mathrm{O}_{7}$ \\
\hline \multirow{2}{*}{$\begin{array}{c}\mathrm{Ca}\left(\mathrm{NO}_{3}\right)_{2} \\
600^{\circ} \mathrm{C}\end{array}$} & $\mathrm{CaHPO}_{4}$ & 1 & \multirow[t]{2}{*}{$\mathrm{Ca}_{2} \mathrm{P}_{2} \mathrm{O}_{7}$} \\
\hline & $\mathrm{Ca}\left(\mathrm{PO}_{3}\right)_{2}$ & 2 & \\
\hline
\end{tabular}

madzu XRD-6000 with $\mathrm{CuK}_{\alpha}$ radiation $(\lambda=$ $1.54178 \AA$ ) was used. Data were collected over the $2 \theta$ range $5-70^{\circ}$, with a step of $0.02^{\circ}$. Identification of phases was achieved by comparing the diffraction patterns of synthesized phosphates with standards of The International Centre for Diffraction Data (ICDD). The program Fullprof was used for calculation of lattice parameters.

Fourier transform infrared spectra (FTIR) were obtained using PerkinElmer Spectrum BX spectrometer (at $1 \mathrm{~cm}^{-1}$ resolution) in the range $400-4000 \mathrm{~cm}^{-1}$ for the samples pressed into the pellets of $\mathrm{KBr}$.

Elements content was determined by X-ray fluorescence spectroscopy (ElvaxLight Spectrometer) and Atomic absorption spectroscopy (Thermo Electron M-Series instrument).

\section{Results and discussion}

\subsection{Interaction in the molten systems}

It was found that the phase composition of obtained crystalline products depends on type of salt melts, nature of alkaline metals and type of calcium phosphate (Table).

The molten chloride-containing systems. According to powder X-ray diffraction results, the general trend of interaction in molten $\mathrm{NaCl}$ was formation of the single phase chlorapatite $\mathrm{Ca}_{10}\left(\mathrm{PO}_{4}\right)_{6} \mathrm{Cl}_{2}$ (Fig. 1a) independent on the type of initial components and molar ratio $\mathrm{P} / \mathrm{Ca}$ in the mixtures (Table). Obtained compound belongs to the hexagonal crystal system (space group $P 63 / \mathrm{m})$ with calculated lattice parameters $(a=9.640(8), c=6.772(1) \AA)$ which are close to corresponding literature data [33]. We can suggest that at heating to $810^{\circ} \mathrm{C}$ the interaction took place according to the scheme (1):

$$
\begin{gathered}
10 \mathrm{CaCO}_{3}+6 \mathrm{NaH}_{2} \mathrm{PO}_{4}+2 \mathrm{NaCl} \rightarrow \quad(1) \\
\mathrm{Ca}_{10}\left(\mathrm{PO}_{4}\right)_{6} \mathrm{Cl}_{2}+4 \mathrm{Na}_{2} \mathrm{CO}_{3}+6 \mathrm{CO}_{2} \uparrow+6 \mathrm{H}_{2} \mathrm{O} \uparrow .
\end{gathered}
$$

Synthesized crystals had needle-like shape in all cases. It should be noted that the largest crystals were obtained when $\mathrm{Ca}\left(\mathrm{PO}_{3}\right)_{2}$ was used as a precursor. The size of the largest crystal was $1.5 \times 2.0 \times 7.0 \mathrm{~mm}^{3}$ (Fig. $2 \mathrm{a}$ ).

The influence of the initial molar ratio P/Ca on the type of obtained products was established for $\mathrm{KCl}$-containing systems. In the cases of systems $\mathrm{CaHPO}_{4}-\mathrm{KCl}$ or $\mathrm{CaCO}_{3}-$ $\mathrm{KH}_{2} \mathrm{PO}_{4}-\mathrm{KCl}$ (at molar ratio $\mathrm{P} / \mathrm{Ca}=1$ ) the single phase double phosphate $\mathrm{KCaPO}_{4}$ was obtained. In the first case, at heating to $810^{\circ} \mathrm{C} \mathrm{KCl}$ played a role of both flux and interacting component (scheme (2)): 

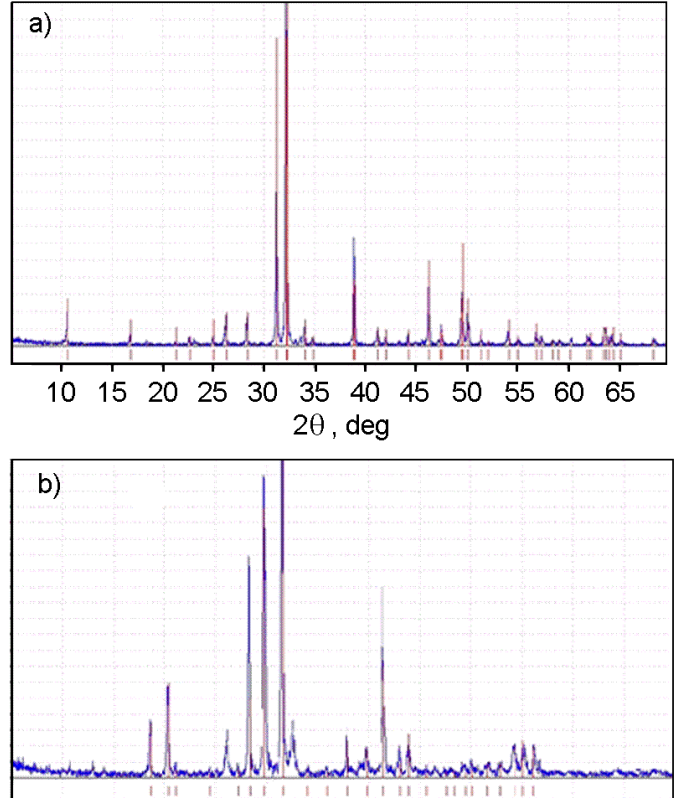

$\begin{array}{llllllllllll}10 & 15 & 20 & 25 & 30 & 35 & 40 & 45 & 50 & 55 & 60 & 65\end{array}$ $2 \theta$, deg

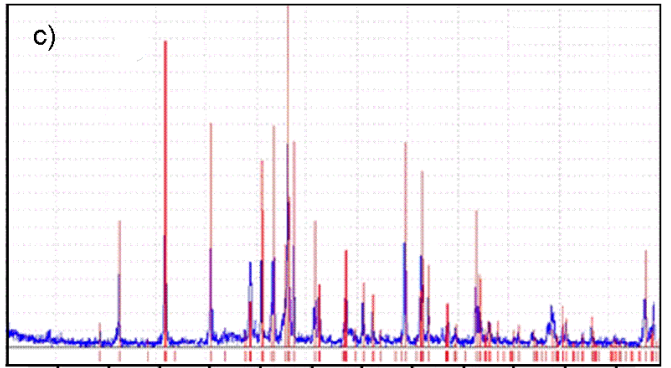

$\begin{array}{llllllllllll}10 & 15 & 20 & 25 & 30 & 35 & 40 & 45 & 50 & 55 & 60 & 65\end{array}$ $2 \theta, \mathrm{deg}$

Fig. 1. Powder XRD patterns (blue color) for synthesized phosphates: $\mathrm{Ca}_{10}\left(\mathrm{PO}_{4}\right)_{6} \mathrm{Cl}_{2}$ (ICDD, \#00-033-0271, red color) (a), $\mathrm{K}_{2} \mathrm{CaP}_{2} \mathrm{O}_{7}$ (ICDD, \#00-022-0805, red color) (b) and $\mathrm{Ca}_{2} \mathrm{PO}_{4} \mathrm{Cl}$ (ICDD, \#00-072-0010, red color) (c).

$$
\mathrm{CaHPO}_{4}+\mathrm{KCl} \rightarrow \mathrm{KCaPO}_{4}+\mathrm{HCl} \uparrow .
$$

On the contrary, in the system $\mathrm{CaCO}_{3}-$ $\mathrm{KH}_{2} \mathrm{PO}_{4}-\mathrm{KCl}$ at heating to $810^{\circ} \mathrm{C}$ the potassium chloride acted only as media of interaction of solids $\mathrm{CaCO}_{3}$ and $\mathrm{KH}_{2} \mathrm{PO}_{4}$ (scheme (3)):

$$
\begin{gathered}
\mathrm{CaCO}_{3}+\mathrm{KH}_{2} \mathrm{PO}_{4} \rightarrow \\
\rightarrow \mathrm{KCaPO}_{4}+\mathrm{CO}_{2} \uparrow+\mathrm{H}_{2} \mathrm{O} \uparrow .
\end{gathered}
$$

Morphological features of these crystals are shown on Fig. 2d. Results of X-ray fluorescence spectroscopy for $\mathrm{KCaPO}_{4}$ showed: $\mathrm{K}, 22.43$ wt. $\%$ (calculated $22.45 \%$ ), Ca, 23.04 wt. \% (calculated $23.01 \%$ ).

In the same time, for systems $\mathrm{Ca}\left(\mathrm{PO}_{3}\right)_{2}-$ $\mathrm{KCl}$ or $\mathrm{CaCO}_{3}-\mathrm{KH}_{2} \mathrm{PO} 4-\mathrm{KCl}$ (at molar ratio

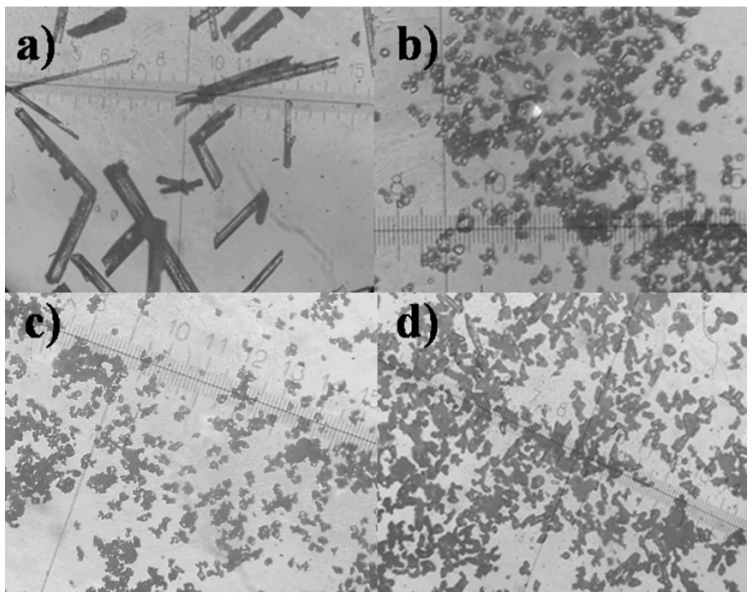

Fig. 2. Microscopic images $(\times 10)$ of complex phosphates synthesized in salts melts: $\mathrm{Ca}_{10}\left(\mathrm{PO}_{4}\right)_{6} \mathrm{Cl}_{2}(\mathrm{a}), \mathrm{K}_{2} \mathrm{CaP}_{2} \mathrm{O}_{7}(\mathrm{~b}), \mathrm{Ca}_{2} \mathrm{P}_{2} \mathrm{O}_{7}$ (c), $\mathrm{KCaPO}_{4}(\mathrm{~d})$.

$\mathrm{P} / \mathrm{Ca}=2$ ) the interaction at heating to $810^{\circ} \mathrm{C}$ resulted in the formation of pyrophosphate $\mathrm{K}_{2} \mathrm{CaP}_{2} \mathrm{O}_{7}$ (Table) according to scheme (4):

$$
\begin{gathered}
\mathrm{CaCO}_{3}+2 \mathrm{KH}_{2} \mathrm{PO}_{4} \rightarrow \\
\rightarrow \mathrm{K}_{2} \mathrm{CaP}_{2} \mathrm{O}_{7}+\mathrm{CO}_{2} \uparrow+2 \mathrm{H}_{2} \mathrm{O} \uparrow .
\end{gathered}
$$

The obtained $\mathrm{K}_{2} \mathrm{CaP}_{2} \mathrm{O}_{7}$ (Fig. 1b) belongs to monoclinic system (space group $P 21 / n$ ) with calculated lattice parameters $(a=9.723(4), b=$ 5.702(1) and $c=12.982(6) \AA, \beta=104.11^{\circ}$ ) which are close to the corresponding data from ICDD (\#00-022-0805) and literature [27]. It was found for this sample: K, 26.75 wt. $\%$ (calculated $26.76 \%$ ), Ca, 13.71 wt. \% (calculated $13.72 \%$ ).

The formation of single phase $\mathrm{Ca}_{2} \mathrm{PO}_{4} \mathrm{Cl}$ (Fig. 1c) was observed in the molten systems $\mathrm{CaHPO}_{4}-\mathrm{CaCl}_{2}$ and $\mathrm{Ca}\left(\mathrm{PO}_{3}\right)_{2}-\mathrm{CaCl}_{2}$ at the temperature $810^{\circ} \mathrm{C}$ during $4 \mathrm{~h}$ (Table). Obtained compound crystallizes in the orthorhombic system (space group $\mathrm{Pbcm}$ ) with calculated lattice parameters: $a=6.186(2)$, $b=6.982(5)$ and $c=10.815(7) \AA$ which are almost identical to those reported by M.Greenblatt et al. [39].

The molten nitrate-containing systems. In the same time, the interaction of $\mathrm{CaHPO}_{4}$ or $\mathrm{Ca}\left(\mathrm{PO}_{3}\right)_{2}$ with molten $\mathrm{Ca}\left(\mathrm{NO}_{3}\right)_{2}$ at the temperature $600^{\circ} \mathrm{C}$ during $5 \mathrm{~h}$ was resulted in formation of $\mathrm{Ca}_{2} \mathrm{P}_{2} \mathrm{O}_{7}$ according to scheme (5) and scheme (6), respectively.

$$
\begin{gathered}
2 \mathrm{CaHPO}_{4} \rightarrow \mathrm{Ca}_{2} \mathrm{P}_{2} \mathrm{O}_{7}+\mathrm{H}_{2} \mathrm{O} \uparrow . \\
2 \mathrm{Ca}\left(\mathrm{PO}_{3}\right)_{2}+2 \mathrm{Ca}\left(\mathrm{NO}_{3}\right)_{2} \rightarrow \\
\rightarrow 2 \mathrm{Ca}_{2} \mathrm{P}_{2} \mathrm{O}_{7}+2 \mathrm{NO}_{2} \uparrow+3 \mathrm{O}_{2} \uparrow .
\end{gathered}
$$


a)

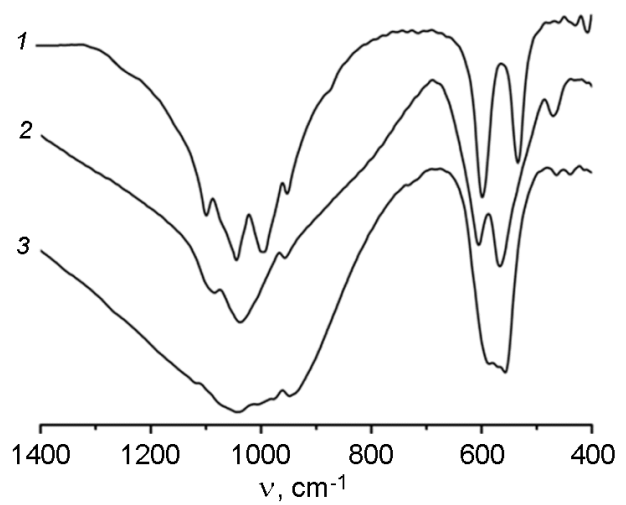

Fig. 3. FTIR-spectra for obtained phosphates: $\mathrm{Na}_{2} \mathrm{CaP}_{2} \mathrm{O}_{7}(4)$, and $\mathrm{K}_{2} \mathrm{CaP}_{2} \mathrm{O}_{7}$ (5).

In the first case, the calcium nitrate was only as media of decomposition of $\mathrm{CaHPO}_{4}$, while in the second scheme, it played a role of both additional source of calcium and flux. The view of obtained crystals is presented on the Fig. 2c.

The difference in mechanisms of phosphates formation also was found for $\mathrm{M}^{l} \mathrm{NO}_{3}-$ containing systems. Thus, interaction between $\mathrm{CaHPO}_{4}$ and $\mathrm{NaNO}_{3}$ at the heating to $450^{\circ} \mathrm{C}$ caused the formation of $\mathrm{NaCaPO}_{4}$ (scheme (7)) while $\mathrm{Ca}_{2} \mathrm{P}_{2} \mathrm{O}_{7}$ was obtained in molten $\mathrm{KNO}_{3}$ under the same conditions:

$$
\begin{gathered}
4 \mathrm{CaHPO}_{4}+4 \mathrm{NaNO}_{3} \rightarrow \\
\rightarrow 4 \mathrm{NaCaPO}_{4}+4 \mathrm{NO}_{2} \uparrow+2 \mathrm{H}_{2} \mathrm{O} \uparrow+\mathrm{O}_{2} \uparrow .
\end{gathered}
$$

Transformation of $\mathrm{Ca}\left(\mathrm{PO}_{3}\right)_{2}$ into $\mathrm{M}_{2} \mathrm{CaP}_{2} \mathrm{O}_{7}$ at the heating to $450^{\circ} \mathrm{C}$ was the common feature for $\mathrm{M}^{\prime} \mathrm{NO}_{3}$-containing systems independent on the nature of alkaline metal (Table) (scheme (8)):

$$
\begin{gathered}
2 \mathrm{Ca}\left(\mathrm{PO}_{3}\right)_{2}+4 \mathrm{M}^{\mathrm{l} N \mathrm{NO}_{3}} \rightarrow \\
\rightarrow 2 \mathrm{M}_{2} \mathrm{CaP}_{2} \mathrm{O}_{7}+4 \mathrm{NO}_{2} \uparrow+7 \mathrm{O}_{2} \uparrow .
\end{gathered}
$$

The main advantages of the proposed synthetic approach. It should be noted that synthesized compounds are used as host lattices for luminescent materials and catalysers of organic reactions $[1-14,16-19$, 24-32]. Such complex phosphates are usually obtained by solid state reactions or crystallization of a high temperature selfflux. These techniques require the high temperature and the interaction between initial components takes place very slowly. Besides, synthesis duration and formation of impurity phases are also disadvantages of such methods. For example, in paper [40] crystals of $\mathrm{Na}_{2} \mathrm{CaP}_{2} \mathrm{O}_{7}$ have been prepared by interaction of $\mathrm{Na}_{2} \mathrm{CO}_{3}, \mathrm{CaCO}_{3}$ and b)

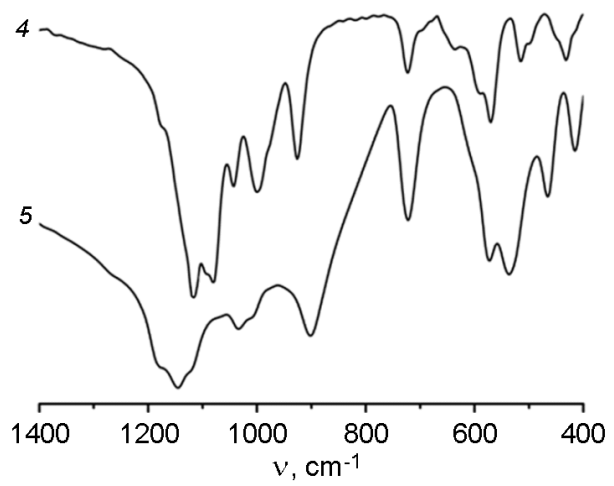

$\mathrm{Ca}_{2} \mathrm{PO}_{4} \mathrm{Cl}(1), \mathrm{Ca}_{10}\left(\mathrm{PO}_{4}\right)_{6} \mathrm{Cl}_{2}$ (2), $\mathrm{KCaPO}_{4}$ $\mathrm{NH}_{4} \mathrm{H}_{2} \mathrm{PO}_{4}$ in proportions $1: 1: 2$, respectively. These materials were ground together and heated progressively to $950^{\circ} \mathrm{C}$ for $24 \mathrm{~h}$ with intermittent cooling and regrinding. In the same time, $\alpha-\mathrm{Ca}_{2} \mathrm{P}_{2} \mathrm{O}_{7}$ was obtained from $\mathrm{CaCO}_{3}$ and $\left(\mathrm{NH}_{4}\right)_{2} \mathrm{HPO}_{4}$. Stoichiometric mixture of starting materials was homogenized by ball milling with $\mathrm{ZrO}_{2}$ media in ethanol for $24 \mathrm{~h}$ and calcined at $1250^{\circ} \mathrm{C}$ for $2 \mathrm{~h}$. The calcined powder was then milled again, pressed into pellet at the pressure and sintered at $1150^{\circ} \mathrm{C}$ for $2-4 \mathrm{~h}$ [20]. In paper [41] $\mathrm{NaCaPO}_{4}$ was synthesized from a stoichiometric mixture of sodium carbonate, calcium carbonate and ammonium phosphate which was first heated at $400^{\circ} \mathrm{C}$, then at $950^{\circ} \mathrm{C}$ with followed crystallization from $\mathrm{Na}_{2} \mathrm{MoO}_{4}$ flux by cooling, from $800^{\circ} \mathrm{C}$ to $200^{\circ} \mathrm{C}$ at a rate of $10^{\circ} \mathrm{C} / \mathrm{h}$. On the contrary, our proposed approach to the preparation of complex calcium phosphates allowed to synthesize such compounds during 5-7 $\mathrm{h}$ at the lower temperatures in nitrate or chloride media.

\subsection{Fourier transform infrared spectroscopy}

The type of phosphate anion in the obtained compounds was determined using Fourier transform infrared spectroscopy (FTIR). The FTIR-spectra for complex phosphates $\mathrm{Ca}_{2} \mathrm{PO}_{4} \mathrm{Cl}, \quad \mathrm{Ca}_{10}\left(\mathrm{PO}_{4}\right)_{6} \mathrm{Cl}_{2}$ and $\mathrm{KCaPO}_{4}$ are similar with respect to intensities and peak positions (Fig. 3a) and confirm the presence of an isolated orthophosphate anion in the obtained compounds. The characteristic broad bands in the range 1160-900 $\mathrm{cm}^{-1}$ belong to asymmetric and symmetric stretching vibrations $\left(v_{a s}(\mathrm{P}-\mathrm{O})\right.$ and $\left.v_{s}(\mathrm{P}-\mathrm{O})\right)$ of $\mathrm{PO}_{4}$-tetrahedra. Corresponding deformation vibrations $\delta(\mathrm{P}-\mathrm{O})$ have been found in the range $620-400 \mathrm{~cm}^{-1}$. The absence of vibrations at frequencies above 
$1200 \mathrm{~cm}^{-1}$ and in the range $700-800 \mathrm{~cm}^{-1}$ indicates that the prepared compounds don't contain condensed phosphate anions [42].

The assignments of the FTIR-bands for $\mathrm{P}_{2} \mathrm{O}_{7}$-group of $\mathrm{Na}_{2} \mathrm{CaP}_{2} \mathrm{O}_{7}$ and $\mathrm{K}_{2} \mathrm{CaP}_{2} \mathrm{O}_{7}$ (Fig. 3b) are made on the basis that $\mathrm{P}_{2} \mathrm{O}_{7^{-}}$ group $\left(\mathrm{O}_{3} \mathrm{P}-\mathrm{O}-\mathrm{PO}_{3}\right)$ can be described as an assembly of the vibrations of the $\mathrm{PO}_{3}$ and the P-O-P groups and $v_{a s}\left(\mathrm{PO}_{3}\right)>v_{s}\left(\mathrm{PO}_{3}\right)>$ $v_{a s}(\mathrm{POP})>v_{s}(\mathrm{POP})$. The broad complex band in the range $1200-920 \mathrm{~cm}^{-1}$ is superposition of asymmetric and symmetric stretching vibrations of $\mathrm{PO}_{3}$-groups. Modes at 900 and $720 \mathrm{~cm}^{-1}$ correspond to symmetric and asymmetric stretching vibrations $\left(v_{a s}(\mathrm{POP})\right.$ and $\left.v_{s}(\mathrm{POP})\right)$ of $\mathrm{P}_{2} \mathrm{O}_{7}$-groups, respectively. The peaks observed in the range $630-400 \mathrm{~cm}^{-1}$ can be assigned to corresponding deformation vibrations [42].

\section{Conclusions}

The particulars of synthesis of complex calcium phosphates in molten chlorides and nitrates were investigated. The main advantages of the proposed synthetic approach were synthesis time and temperature reduction comparing with solid state reactions and crystallization of a high temperature self-flux. Powder X-ray diffraction data indicated that the phase composition of the obtained crystalline products depended on the type of salt melts and initial components, and nature of alkaline metals. Obtained results showed that molten chlorides and nitrates could play a role of both flux and interacting component during phosphates formation.

\section{References}

1. K.N.Shinde, S.J.Dhoble, A.Kumar, J.Rare Earths, 29, 527 (2011).

2. Z.Yang, G.Yanga, S.Wang et al., Mater.Lett., 62, 1884 (2008).

3. B.K.Grandh, V.R.Bandi, K.Jang et al., Ceram. Int., 38, 6273 (2012).

4. Y.Wang, M.G.Brik, P.Dorenbos et al., J.Phys. Chem. C, 118, 7002 (2014).

5. Y.Wang, J.Zhang, D.Hou et al., Opt.Mater., 34, 1214 (2012).

6. J.Hu, H.Xie, Y.Huang et al., Appl.Phys.B: Lasers Opt., 114, 461 (2014).

7. S.Zhang, Y.Huang, W.Kai et al., Solid State Lett., 13, J11 (2010).

8. K.N.Shinde, S.J.Dhoble, A.Kumar, Physica B, 406, 94 (2011).

9. D.K.Yima, I.S.Cho, C.W.Lee et al., Opt. Mater., 33, 1036 (2011).

10. B.K.Grandhe, V.R.Bandi, K.Jang et al., J.Alloys Compd., 509, 7937 (2011).

11. B.V.Ratnam, M.Jayasimhadri, G.Bhaskar Kumar et al., J.Alloys Compd., 564, 100 (2013).
12. L.Guan, C.Liu, X.Li et al., Mater.Res.Bull., 46, 1496 (2011).

13. S.Zhang, Y.Huang, H.J.Seo, J.Electrochem. Soc., 157, J261 (2010).

14. C.Qin, Y.Huang, L.Shiet, J.Phys. D:Appl.Phys., 42, 185105 (2009).

15. S.Jalota, S.B.Bhaduri, A.C.Tas, J.Biomed. Mater. Res., 80, 304 (2007).

16. R.Pang, C.Li, S.Zhang et al., Mater.Chem. Phys., 113, 215 (2009).

17. Z.Hao, J.Zhang, X.Zhang et al., J.Luminescence, 128, 941 (2008).

18. N.Ta, D.Chen, J.Alloys Compd., 484, 514 (2009).

19. J.H.Hong, J.M.Lee, H.Kim et al., Appl.Catal., A:396, 194 (2011).

20. J.J.Bian, D.W.Kim, K.S.Hong, Mater.Lett., 58, 347 (2004).

21. J.J.Bian, D.W.Kim, K.S.Hong, J.Eur.Ceram. Soc., 23, 2589 (2003).

22. F.Xiao, E.H.Song, Q.Y.Zhang, Spectrochim. Acta, Part A, 122, 343 (2014).

23. E.Song, W.Zhaon, X.Dou et al., J.Luminescence., 132, 1462 (2012).

24. J.Bennazha, M.Zahouily, S.Sebti et al., Catal. Commun., 2, 101 (2001).

25. M.Zahouily, Y.Abrouki, A.Rayadh, Tetrahedron Lett., 43, 7729 (2002).

26. M.Zahouily, M.Salah, J.Bennazhaet et al., Tetrahedron Lett., 44, 3255 (2003).

27. E.Song, W.Zhao, G.Zhou et al., Curr.Appl. Phys., 11, 1374 (2011).

28. J.A.Wani, N.S.Dhoble, N.S.Kokode et al., Adv. Mater. Lett., 5, 459 (2014).

29. Y.C.Chiu, W.R.Liu, C.K.Changet et al., J. Mater. Chem., 20, 1755 (2010).

30. D.Y.Wang, Y.C.Chiu, C.H.Huang et al., J. Lumin., 148, 151 (2014).

31. R.Yu, C.Guo, T.Li et al., Curr.Appl.Phys., 13, 880 (2013).

32. Y.C.Chiu, W.R.Liu, C.K.Chang et al., J.Rare Earths, 28, 250 (2010).

33. R.J.Wiglusz, Z.Drulis-Kawa, R.Pazik et al., Dalton Trans., 44, 6918 (2015).

34. M.Mehnaoui, R.Ternane, G.Panczer et al., $J$. Phys.:Condens. Matter., 20, 275227 (2008).

35. R.Pazik, J.M.Nedelec, R.J.Wiglusz, Cryst. Eng. Comm., 16, 5308 (2014).

36. O.V.Livitska, N.Yu.Strutynska, I.V.Zatovsky et al., Solid State Phenom., 230, 297 (2015).

37. O.V.Livitska, N.Yu.Strutynska, I.V.Zatovsky et al., Cryst. Res. Technol., 50, 626 (2015).

38. O.Livitska, N.Strutynska, I.Zatovsky et al., $J$. Cryst. Growth.,434, 30 (2016).

39. M.Greenblatt, E.Banks, B.Post, Acta Crystal$\log r .$, 23, 166 (1967).

40. J.Bennazha, A.Boukhari, E.M.Holt, Solid State Sci., 1, 373 (1999).

41. M.Ben Amara, M.Vlasse, G.Le Flem et al., Acta Crystallogr. C, 39, 1483 (1983).

42. K.Nakamoto, Infrared and Raman Spectra of Inorganic and Coordination Compounds. Part A, 5th ed, John Wiley\&Sons, New York (1997). 